\title{
Introduction of Mobile IT Solutions in the Management of Energy Enterprises (on the Example of Company "Kuban-Energy")
}

\author{
Yuriy Dreizis ${ }^{1}$, Irina Grigoryan ${ }^{2}$, Elina Pilosyan ${ }^{1}$ and Nadezhda Kazakova ${ }^{1}$ \\ ${ }^{1}$ Sochi State University, Plastunskaya str., 94-1, Sochi, 354000, Russia \\ ${ }^{2}$ Ltd company "AD-technologies in management", Moscow, Russia
}

\begin{abstract}
Use of mobile devices for performance of corporate tasks becomes more and more widespread way of increase in overall performance of the energy enterprise. Need to accelerate considerably and to effectively organize work of all organization is the main objective of use of technologies of corporate mobility. For this purpose, it is necessary to choose information network (mobile network operator), mobile devices, and means of authentication of the user (for safety of data). The analysis of opportunities of use of mobile technologies and technical means in production and administrative activity of the energy enterprises was a research objective. The analysis of cover zones and tariff plans of various operators of cellular networks was made for definition of opportunities of implementation of technologies of corporate mobility on the example of the territory of Krasnodar region. The most suitable suppliers of cellular communication in the region were also defined. The analysis of the technical means necessary for realization of mobile solutions and the analysis of means of authentication of users, which allow providing data protection from strangers was executed within the research.It is shown that use of mobile technologies in management of the companies will expand functionality of business processes at the energy enterprise, will promote increase in overall performance, growth of competitiveness.
\end{abstract}

\section{Introduction}

Many large companies try to avoid formation of paper documents, to provide remote tracking of the tasks (stages of tasks) which are carried out by employees and to increase efficiency of the performed works now. Various energy enterprises, which are engaged in service and repair of highways, railroads, power plants and power lines, gas-and oil pipelines, etc., can be carried to such organizations. Important quickly and accurately to give tasks to workers of the serving and repair crews, to trace stages of performance of repair work in real time in such companies.

Emergence of new mobile operating systems, such as, for example, Android and iOS and also emergence of mobile devices which function on their basis (smartphones, tablets, iPods, etc.) gave the chance to realize new corporate opportunities in modern economy and administrative activity which are based on technologies of mobility. 
Realization of corporate mobility allows employees of the companies to get access to information space of the energy enterprise, to its corporate information systems and resources, systems and resources of decision-making by means of tablets and smartphones in a cover zone of information network [1].

Introduction of these devices in a daily corporate governance practice was promoted also by ampler opportunities for use of high-speed broadband information networks. Information transfer speeds and in the Internet increased in networks of cellular communication in recent years on several orders.

The list of staff of various companies for whom mobile access to information resources of the energy enterprises became necessary in recent years considerably increased:

- heads and managers of all control links;

- marketing specialists, to logistics and other business processes at the energy enterprise;

- employees who are engaged in maintenance and repair of various equipment;

- security service specialists of the energy enterprises;

- the staff of divisions of technical assistance (repairing or surveying the systems of electro-and water supply, heating, gas supply, etc.);

- other employees.

In production and administrative activity of the energy enterprises of appropriate technologies of mobility, it is possible to carry to positive factors of use:

- efficiency of response of employees and directors to the arising external and internal production and administrative inquiries;

- increase in speed and quality of realization of separate business processes;

- document flow acceleration, especially with remote workers and divisions;

- possibility of performance of business processes by the field and mobile employees (for example, mobile teams of maintenance) who are out of the energy enterprise;

- use by employees in the course of operation of own mobile devices owing to what at the energy enterprise parallel IT infrastructure of the energy enterprise in an information field of the energy enterprise, other can be created [2].

Use of mobile technologies will allow providing, for example, for workers of maintenance and repairing at the energy enterprises power - gas-heat and water supply:

- submission of requisitions for materials and equipment necessary for work;

- expeditious obtaining orders on performance of work and necessary technical documentation (electric circuits, plans, floor-by-floor plans of communications, etc.);

- creation of reports from the place of accident before work, etc.

Typical business process of performance of work, based on mobile technologies, is given in figure 1 [4]. 


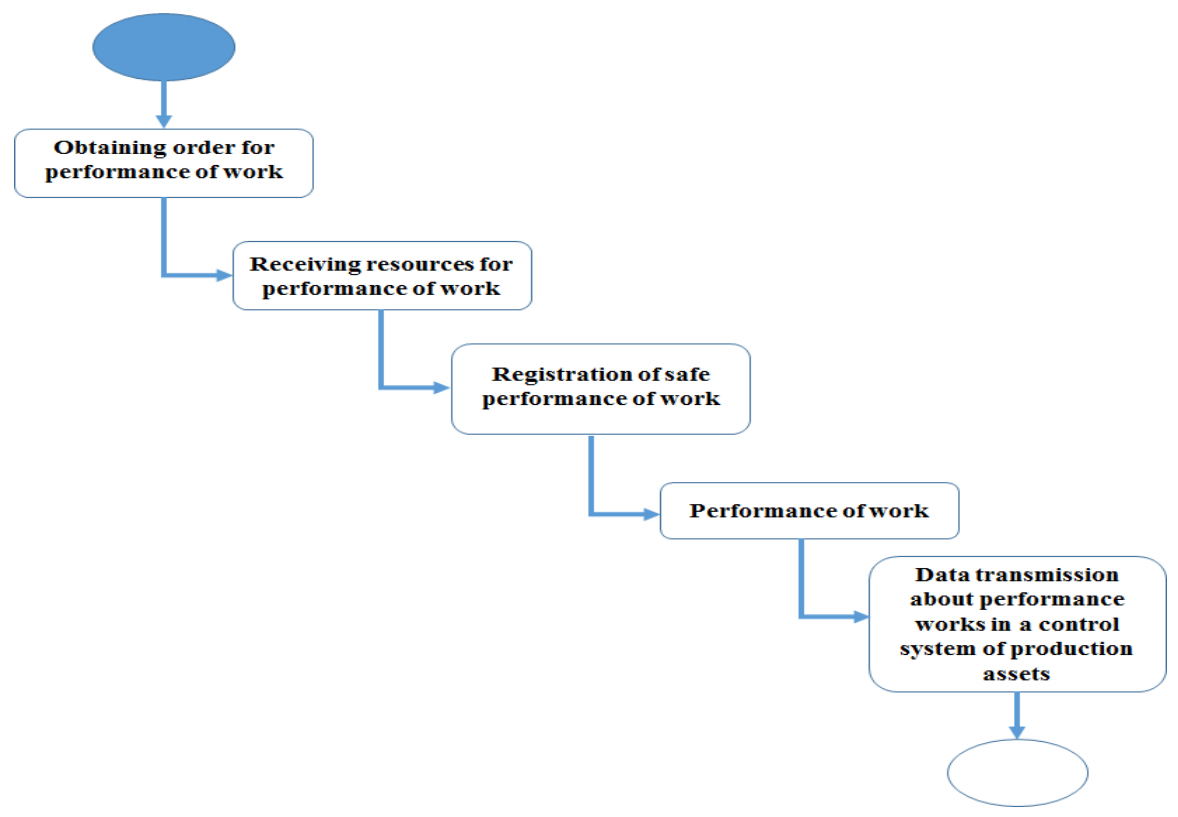

Fig. 1: Business process of performance of work, based on technologies of remote access to an information system of the energy enterprise

\section{Materials and methods}

Mobile technologies actively develop today and begin to be used actively in administrative activity in the most different fields of economic activity, in management of economic processes. Research objective is the analysis of opportunities of use of mobile technologies and technical means in production and administrative activity of the energy enterprises.

The research was carried out at the subsidiary of energy enterprise "Kuban-energy" [3]. The main activity of this enterprise is transmission and distribution of electricity via $110 \mathrm{kV}$ and lower electric networks for electricity consumers of Krasnodar Territory and the Republic of Adygea. The activity of energy enterprise "Kuban-energy" on power transmission is regulated by the state in terms of establishing tariffs for power transmission and rates for technological connection, as well as ensuring non-discriminatory access of consumers to electric networks. Repair teams of this enterprise carry out inspection and repair works at facilities belonging to this organization. The repair service needs to form a repair team as soon as possible and issue a task. It is important for the employees of repair teams to quickly obtain a task for performance of works (work permit or order depending on the type of work required). The purpose of the research is to analyze the possibility of introducing mobile technologies and technical means into the production and management activities of the working teams at the energy enterprise, as well as to develop proposals for automation of individual business processes using mobile applications.

Object of research is:

- the analysis of technical means for realization of mobile solutions, i.e. the analysis of tablets, etc. IT devices;

- the analysis of tariffs of mobile operators (the operators working across Russia and in the CIS countries are chosen);

- the analysis of means of authentication of users which allow to provide data protection from strangers (two options of data protection are chosen: digital signature, NFC tags). 
The statistical data given the cellular companies about cover zones and tariffs, data on the prices of mobile devices of the leading retail chain stores were used in the course of the research.

\section{The analysis of the fixed technical means and tariffs of cellular communication for realization of mobile solutions}

\subsection{Analysis of tariffs of networks of cellular communication}

Access for users to corporate information infrastructure of the energy enterprises and the organizations, to technologies of mobile commerce, mobile content, to resources the Internet is carried out by means of mobile devices based on information networks of standards $3 \mathrm{G}$ and $4 \mathrm{G}$ in recent years. All operators working across Russia and the CIS for the choice of a tariff were analyzed. The analysis of tariffs is carried out on the example of the cellular companies working at the territory of Krasnodar region of Russia as tariff plans of the same operators differ in different regions.

The following parameters were the main criteria for selection of a tariff plan:

- the tariff is intended for work on the Internet;

- area of a covering of network of the operator;

- existence of standards $3 \mathrm{G}$ and $4 \mathrm{G}$;

- use cost.

It is necessary to define whether information network of the operator covers the necessary territory precisely to define a possibility of implementation of corporate mobility in the company. It is important to analyze coverage maps of the territory the chosen operators and to define the most suitable supplier of cellular communication for this purpose. Coverage maps of mobile network operators in the territory of Krasnodar Region are submitted in fig. 2-6 [5-10].

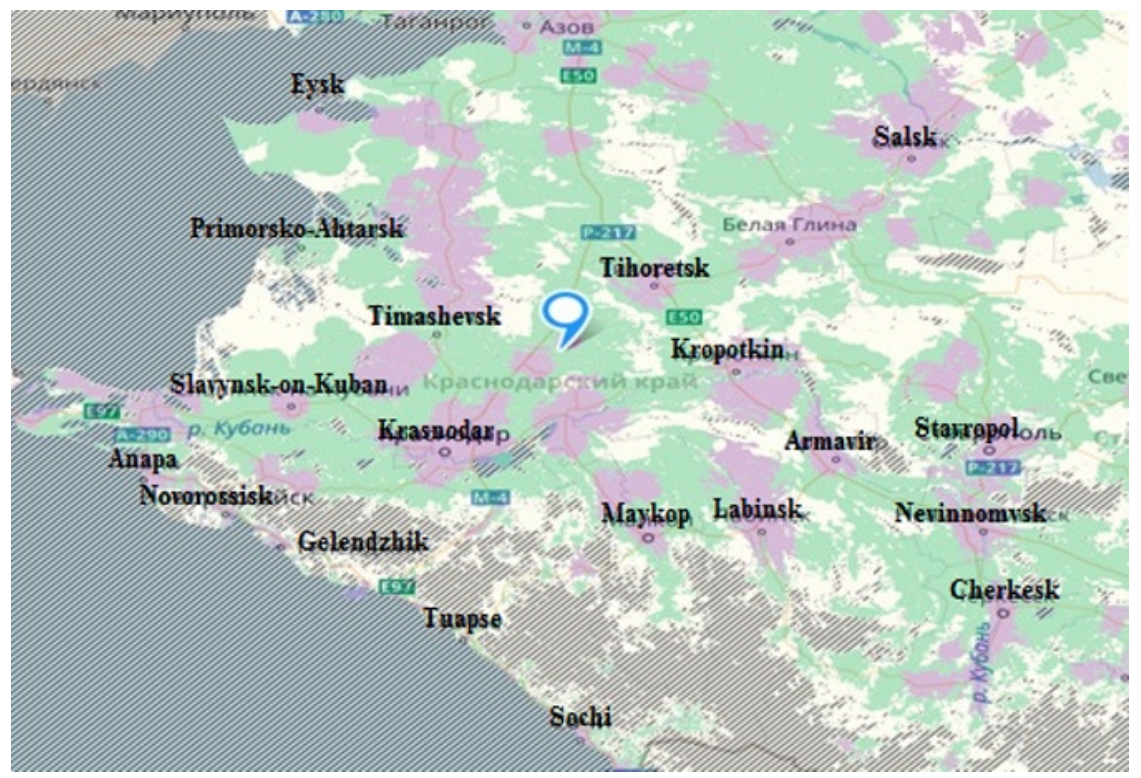

Fig. 2: Coverage map of Megafon operator (3G, 4G) 


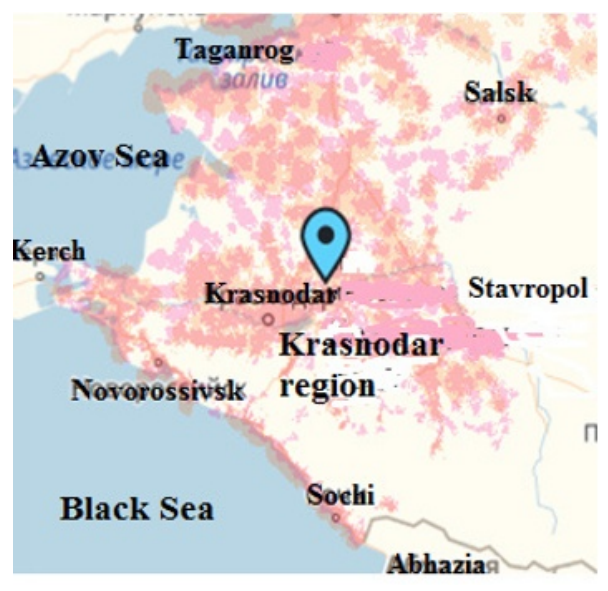

Fig. 3. Coverage map of Tele2 operator (3G, 4G)
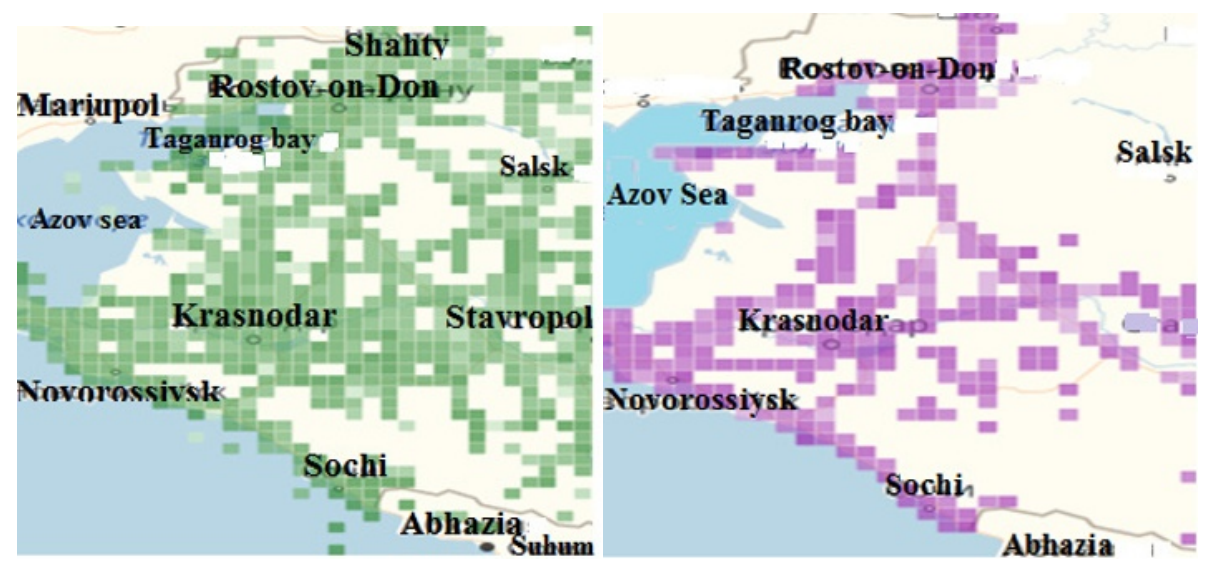

Fig. 4. Coverage map of Beeline operator (3G, 4G)
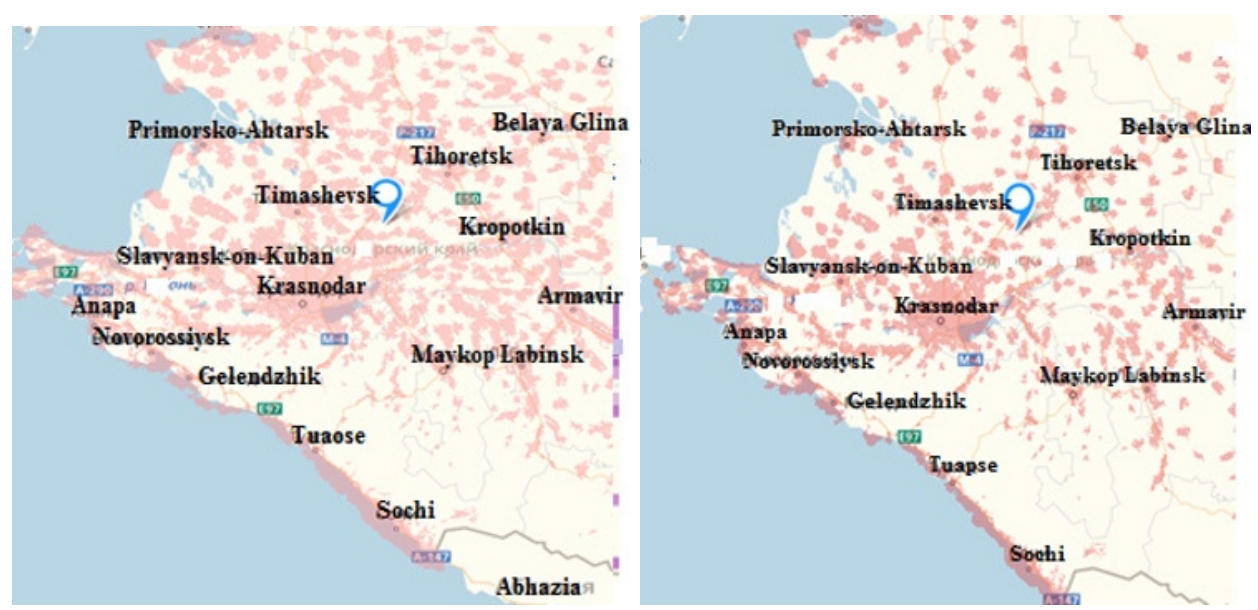

Fig. 5. Coverage map of the operator of MTS (3G, 4G) 


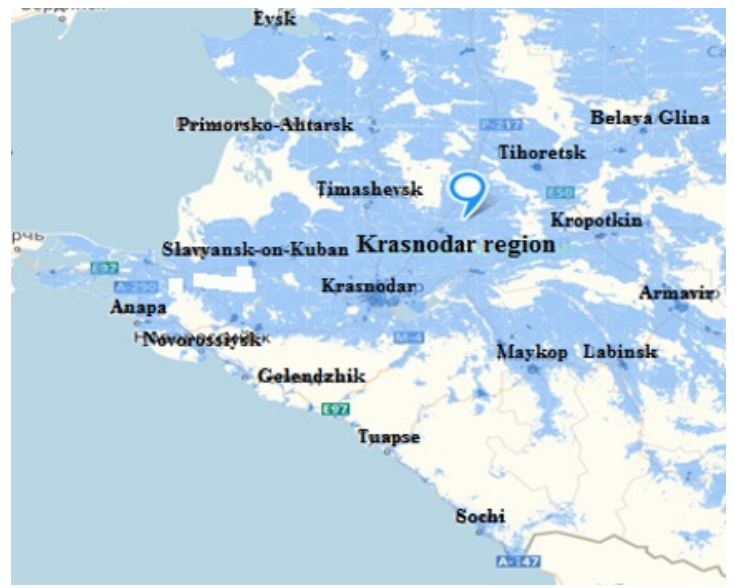

Fig. 6. Coverage map of Yota operator (3G, 4G)

It should be noted that the majority of tariffs have different tariff plans and additional functions, and it influences the price in turn.

Tariffs of the following operators are presented in table 1: Megaphone, Beeline, MTS, Tele2, Yota. These companies work through the whole country and are the main suppliers of cellular communication in Russia and the CIS countries [5-10].

Table 1: Analysis of tariffs of cellular communication [Cellular Operator Coverage Map, 2019; The official website of the cellular operator MegaFon, 2019; The official website of the cellular operator Bilajn, 2019; The official website of the cellular operator MTS, 2019; The official website of the cellular operator Tele-2, 2019; The official website of the cellular operator Yota, 2019]

\begin{tabular}{|c|c|c|c|c|c|c|c|}
\hline \multirow{2}{*}{$\begin{array}{c}\text { Name of the } \\
\text { operator }\end{array}$} & \multirow{2}{*}{$\begin{array}{c}\text { Name } \\
\text { of a tariff }\end{array}$} & \multirow{2}{*}{ Tariff plan } & \multirow{2}{*}{$\begin{array}{l}\text { Internet } \\
\text { traffic }\end{array}$} & \multicolumn{2}{|c|}{$\begin{array}{c}\text { Basic structure } \\
\text { of a set }\end{array}$} & \multirow{2}{*}{ In addition } & \multirow{2}{*}{$\begin{array}{l}\text { Cost, } \\
\text { rub/month }\end{array}$} \\
\hline & & & & $\begin{array}{l}\text { SMS, } \\
\text { piece }\end{array}$ & $\begin{array}{l}\text { Calls, } \\
\text { min. }\end{array}$ & & \\
\hline \multirow{8}{*}{ Megafon } & \multirow{4}{*}{$\begin{array}{l}\text { Business } \\
\text { tariff } \\
\text { "Operate" }\end{array}$} & Specialist & $7 \mathrm{~Gb}$ & 300 & 300 & - & 450 \\
\hline & & Expert & $\begin{array}{c}\text { Unlimited } \\
\text { Internet }\end{array}$ & 300 & 600 & - & 700 \\
\hline & & Manager & $\begin{array}{l}\text { Unlimited } \\
\text { Internet }\end{array}$ & 500 & 1000 & $\begin{array}{c}\text { MegaFon } \\
\text { Antibreaking, } \\
\text { mobile cloud }\end{array}$ & 1000 \\
\hline & & Head & $\begin{array}{l}\text { Unlimited } \\
\text { Internet }\end{array}$ & 1000 & 2500 & $\begin{array}{l}\text { MegaFon Anti- } \\
\text { breaking, } \\
\text { mobile cloud }\end{array}$ & 1600 \\
\hline & \multirow{4}{*}{$\begin{array}{l}\text { Corporate } \\
\text { Megafon } \\
\text { Online }\end{array}$} & $\mathrm{S}$ & $5 \mathrm{~Gb}$ & - & - & - & 350 \\
\hline & & $\mathrm{M}$ & $10 \mathrm{~Gb}$ & - & - & - & 590 \\
\hline & & $\mathrm{L}$ & $20 \mathrm{~Gb}$ & - & - & - & 890 \\
\hline & & $\mathrm{XL}$ & $40 \mathrm{~Gb}$ & - & - & - & 1290 \\
\hline \multirow{3}{*}{ Beeline } & \multirow{3}{*}{$\begin{array}{l}\text { Forcing } \\
\text { for } \\
\text { business }\end{array}$} & $6 \mathrm{~Gb}$ & $6 \mathrm{~Gb}$ & & - & $\begin{array}{l}\text { It is connected } \\
\text { separately }\end{array}$ & 390 \\
\hline & & $12 \mathrm{~Gb}$ & $12 \mathrm{~Gb}$ & - & - & $\begin{array}{c}\text { It is connected } \\
\text { separately }\end{array}$ & 600 \\
\hline & & $30 \mathrm{~Gb}$ & $30 \mathrm{~Gb}$ & - & - & $\begin{array}{l}\text { It is connected } \\
\text { separately }\end{array}$ & 1200 \\
\hline \multirow{4}{*}{ MTC } & \multirow{3}{*}{$\begin{array}{c}\text { MTC } \\
\text { Business } \\
\text { Smart }\end{array}$} & \multirow{3}{*}{-} & $10 \mathrm{~Gb}$ & - & - & - & 450 \\
\hline & & & $20 \mathrm{~Gb}$ & - & - & - & 550 \\
\hline & & & $\begin{array}{c}\text { Unlimited } \\
\text { Internet }\end{array}$ & - & - & - & 850 \\
\hline & $\begin{array}{c}\text { For the } \\
\text { tablet }\end{array}$ & - & $10 \mathrm{~Gb}$ & - & - & $\begin{array}{l}\text { Cloudy storage } 50 \\
\text { Gb, antivirus, the } \\
\text { protected data } \\
\text { transmission (at }\end{array}$ & 400 \\
\hline
\end{tabular}




\begin{tabular}{|c|c|c|c|c|c|c|c|}
\hline & & & & & & choice) & \\
\hline \multirow{4}{*}{ Tele 2} & \multirow{4}{*}{$\begin{array}{c}\text { My } \\
\text { Business }\end{array}$} & XS & $3 \mathrm{~Gb}$ & 50 & 300 & \multirow{4}{*}{$\begin{array}{l}\text { Unlimited calls by } \\
\text { all Russia on Tele } 2\end{array}$} & 250 \\
\hline & & $\mathrm{S}$ & $15 \mathrm{~Gb}$ & 100 & 500 & & 370 \\
\hline & & $\mathrm{M}$ & $25 \mathrm{~Gb}$ & 200 & 1000 & & 550 \\
\hline & & $\mathrm{L}$ & $35 \mathrm{~Gb}$ & 300 & 2000 & & 850 \\
\hline \multirow{4}{*}{ Yota } & \multirow{4}{*}{$\begin{array}{l}\text { Yota } \\
\text { for the } \\
\text { tablet }\end{array}$} & \multirow{4}{*}{ - } & $7 \mathrm{~Gb}$ & - & - & - & 255 \\
\hline & & & $15 \mathrm{~Gb}$ & - & - & - & 305 \\
\hline & & & $30 \mathrm{~Gb}$ & - & - & - & 355 \\
\hline & & & $50 \mathrm{~Gb}$ & - & - & - & 405 \\
\hline
\end{tabular}

\subsection{Analysis of mobile devices}

The market of modern mobile devices is various. The set of additional functions, such as work with graphics, the system of navigation, photo and video filming have new generations of tablets and smart-phones.

As the main objective of the mobile device is distant work with employees (obtaining reports, tracking of stages of works, etc.), the tablet compatible to mobile version of the corporate program and having low cost is required. For the analysis of the market of tablets, the following criteria were chosen:

- memory size up to $8 \mathrm{~GB}$ as work of the main corporate application does not require the large volume of memory;

Android operating system. This OS was chosen as has the following advantages: ease of development of software, a possibility of increase in memory (SD card), it is easy to adapt any applications for OS;

- low cost.

Low price of mobile devices in combination with acceptable technical requirements was priority criterion and was focused on financial opportunities of many energy enterprises.

The tablets meeting the above-stated criteria are presented in table 2.

Table 2: Analysis of tablets

\begin{tabular}{|c|c|c|c|c|c|}
\hline Name of model & Операционная система & $\begin{array}{c}\text { Объем } \\
\text { оперативной } \\
\text { памяти }\end{array}$ & $\begin{array}{c}\text { Встроенная } \\
\text { память }\end{array}$ & Модуль связи & $\begin{array}{c}\text { Price, } \\
\text { rub. }\end{array}$ \\
\hline $\begin{array}{c}\text { Prestigio } \\
\text { MultiPad Wize }\end{array}$ & Android 7.0 & $1 \mathrm{~Gb}$ & $8 \mathrm{~Gb}$ & $3 \mathrm{G}, \mathrm{LTE}$ & 5490 \\
\hline $\begin{array}{c}\text { Samsung } \\
\text { Galaxy Tab A }\end{array}$ & Android 5.1 & $1.5 \mathrm{~Gb}$ & $8 \mathrm{~Gb}$ & 3G, LTE & 9990 \\
\hline $\begin{array}{c}\text { Digma Optima } \\
8100 \mathrm{R}\end{array}$ & Android 6.0 & $1 \mathrm{~Gb}$ & $8 \mathrm{~Gb}$ & 3G, LTE & 4590 \\
\hline
\end{tabular}

\subsection{Analysis of means of authentication of the user}

Two options of data protection were chosen: the digital signature and NFC tags for the analysis.

\subsubsection{NFC tags}

NFC tags have a big range of application now: cash cards, possibility of contactless payment, etc. This means of authentication represents the microchip. It allows placing it in any convenient subject (for example, a charm, a bracelet, etc.).

The main advantage of a NFC tag is that it works without food. For activation, it is necessary to place a tag in a certain range (several centimeters from the active device, for example, of the tablet or the smartphone). Therefore, it can be used on objects, which have 
no Internet access. In addition, it is worth carrying their low price to advantages of these tags. It is allowed even to the low budget organizations to use this means of authentication [11].

Tags without a possibility of rewriting of data for authentication of staff of the energy enterprise are necessary. It is necessary for prevention of gaining access to data of strangers.

The analysis of types of NFC tags is presented in table [12-13].

Table 3: Analysis of NFC tags

\begin{tabular}{|c|c|c|c|}
\hline Type of tags & $\begin{array}{c}\text { Possibility of } \\
\text { rewriting of data }\end{array}$ & $\begin{array}{c}\text { The volume of the } \\
\text { stored data }\end{array}$ & Data transmission speed \\
\hline Type 1 & Yes & $48 \mathrm{~b}$ & 106 кбит/с \\
\hline Tyре 2 & Yes & $4 \mathrm{~Kb}$ & 106 кбит $/ \mathrm{c}$ \\
\hline Tyре 3 & No & $4 \mathrm{~Kb}$ & 212 кбит/c \\
\hline Tyрe 4 & No & $32 \mathrm{~Kb}$ & $106-424$ кбит $/ \mathrm{c}$ \\
\hline
\end{tabular}

The main advantage of NFC tags is that it is possible to work with them without the Internet. These tags will be suitable for the hilly terrain, lowlands when performing inspections and repair work on power supply networks, gas pipelines, etc. objects since often there is no communication.

\subsubsection{Digital signature}

The Digital Signature (DS) is the main way of authentication of the user. This way of data protection is widely used in all fields of activity. The main advantage of DS is exact identification of the user, however it should be noted that use of this way of information security is impossible without Internet access, i.e. the digital signature cannot be used at the energy enterprises, which do not have access to network [12-13.

Digital signature should refer annual certification of each user to shortcomings. Certification of one user will cost the organization 1500 rubles for the minimum tariff.

\section{$4 \quad$ Analysis of Results}

Mobile solutions, which are proposed for management of separate business processes of the energy enterprises, have to rely on implementation of the following main requirements:

- they have to be independent of the platform of the mobile device and of that information platform on the basis of which the information management system works with the energy enterprise;

- they have to provide continuous synchronization of the used mobile devices with the information management system by the energy enterprise;

- providing safety requirements is necessary at information exchange of remote mobile devices and the energy enterprises.

In addition, of use of mobile technologies and mobile technical means in production and administrative activity of the energy enterprises will become:

- improvement of the business processes realized at the energy enterprise and processes of planning of the works performed far off,

- ensuring interaction with the systems of information exchange at the energy enterprise;

- timely obtaining necessary and authentic data on the performed works and also fast adoption of management decisions at distant work;

- ensuring functioning of information security systems of the energy enterprises and also the used applied software solutions (especially for the energy enterprises of the energy enterprises of the sphere of life support of the population and the state), 
- reduction of terms of performance of production works and increase in their quality, etc.

The following conclusions because of the analysis of opportunities of use of mobile technologies and technical means in production and administrative activity of the energy enterprises were drawn:

- it is more favorable to get the tariff plan "Business of Smart" of the operator of MTS, or the tariff plan "Yota for the tablet" of Yota operator (depending on necessary quantity of Internet traffic) for transfer of packages of data). These tariffs were chosen for the following reasons: they have no additional "unnecessary" functions (an antivirus, unlimited calls, etc.) which increase tariff cost; relative low cost (in this case MTS concedes to Yota); these tariffs are developed for work with tablets;

- for performance of the tasks set by the organization, employees need to report on stages of the performed work. The following tablets were chosen: Digma Optima 8100R, Prestigio MultiPad Wize as performance of these operations in the mobile application does not require large volumes of random access memory. These tablets have $1 \mathrm{~GB}$ of the RAM and $8 \mathrm{~GB}$ of ROM. These tablets were chosen since they belong to the category of the budget devices (the tablet price up to 10000). Samsung Galaxy Tab A also belongs to this price category, but it is significantly more expensive than the chosen tablets, and on characteristics has no considerable differences;

- this way of authentication of the user is unprofitable for the low budget organizations and the energy enterprises (in the first case) working in the hilly terrain (in the second case) as certification of employees needs to be made for use of the EDS annually, and it is possible to carry out authentication only at connection to the Internet.

A choice was made in favor of a NFC tag in this case as:

- it is got once,

- gives possibilities of authentication in places without Internet access,

- the tag is much cheaper than the digital signature.

It is necessary to choose NFC tags of the 3rd and 4th type for authentication of users since tags of these types are not available possibilities of rewriting of data.

\section{Conclusion}

Criteria for selection of means for realization of mobile solutions were designated in a research. The analysis of the market of cellular communication and tablets was carried out. In addition, ways of information security from strangers (NFC tags and the digital signature) were considered.

Realization of mobile solutions at the energy enterprise allows to monitor remotely performance of work in real time by means of the tablet (access to the Internet is for this purpose necessary). The staff of the energy enterprise can receive far off new tasks, quickly report on the performed work, note work stages, etc., having Internet access. It allows to accelerate considerably and to effectively organize work of all organization since leads to reduction of expenses of time for performance of certain functions (for example, on delivery/receiving tasks, petition of participants of process, etc.).

Use of mobile technologies in management of the companies will expand functionality of business processes at the energy enterprise, will promote increase in overall performance, growth of its competitiveness.

Results of researches were used at the organization of information exchange of repair crews with the information management system by the "Kuban-energy energy enterprise" of JSC "Rosseti”. 


\section{References}

1. G. Ladyzhenskij, Distributed Information Systems and Databases. Available at: http://articles.org.ru/cfaq/index.php?qid= 1306\&catid=54

2. L.P. Gavrilov, Innovative Technologies in Commerce and Business Available at: https://studme.org/1211102220569/informatika/innovatsionnye_tehnologii_v_kommert sii_i_biznese

3. Public Joint-Stock Company "Energy and Electrification of the Kuban" URL: http://www.kubanenergo.ru (last accessed: 28.04.2018).

4. Yu. Dreizis, I. Grigoryan and N. Kazakova, European Journal of Computer Science 4(1), 3-11 (2018)

5. Coverage cards of mobile operators. Available at: https://4g-faq.ru/karty-pokrytiya/

6. Official website of the operator MegaFon. Available at: https://www.megafon.ru/

7. Official website of the operator Beeline, Available at: https://www.beeline.ru/

8. Official website of the operator MTS. Available at: https://www.mts.ru/

9. Official website of the operator Tele-2 Available at: https://tele2.ru/

10. Official website of the operator Yota Available at: https://www.yota.ru/

11. NFC-tags. Available at: https://android-pays.ru/nfc-metki-dlya-oplaty.html

12. N.E. Kazakova, U.I. Drejzis, I.V. Grigoryan, Academy of Knowledge Bulletin 32(3), 105-115 (2019)

13. N.E. Kazakova, U.I. Drejzis, All-Russian Youth Scientific and Practical Conference: « YOUTH-SCIENCE - X Actual problems of tourism, hospitality, catering and technical service», 673-678, SGU, Sochi (2019) 